\title{
Dogmatyzacja Prawdy
}

\section{ks. archimandryta Warsonofiusz Doroszkiewicz}

Katedra Teologii Prawosławnej Uniwersytetu w Białymstoku

warsonofiusz@gmail.com

\begin{abstract}
ks. archimandryta Warsonofiusz Doroszkiewicz, Dogmatization of the Truth, Elpis, 16 2014: 113-118.
Abstract: Since the beginning of time, man has searched for answers to the questions that tormented him concerning how he came into being, how the world came into existence and if objective truth exists. The problem of defining the idea of truth caused unrest first of all for ancient philosophers and one can find a few formulations defining this concept in ancient Greek metaphysics.

The first to define the concept of truth was Aristotle. The Old Testament had its own truth. We do not speak of a dogma of the Old or New Testament, but we speak of the truth or truths of the Old or New Testament or generally of truths contained in the Holy Scripture. On the other hand, the New Testament proclaimed that Truth had become man. When interpreting the idea of the truth in the New Testament, St. Clemens of Rome stated, that not only Christ Himself is the very Truth but all he proclaims is the very truth. The history of the Church witnesses to the fact of how truth, that was attacked by heretics, transformed itself into dogma. For two thousand years, the Church has preserved the dogmatic definitions of the Holy Ecumenical Councils, which are the foundation of our faith and the very guarantee of our proper growth in Christ and finally, of our salvation.
\end{abstract}

\begin{abstract}
Streszczenie: Od samego początku człowiek poszukiwał odpowiedzi na dręczące go pytania odnośnie początków jego istnienia, jak powstał świat i czy istnieje jakaś obiektywna prawda. Problem zdefiniowania pojęcia prawdy trapił w starożytności przede wszystkim filozofów a w starożytnej greckiej metafizyce można znaleźć kilka sformułowań określających to pojęcie. Pierwszy kto dokonał zdefiniowania pojęcia prawdy był Arystoteles. Stary Testament miał swoją prawdę. Nie mówimy bowiem dogmaty Starego czy też Nowego Testamentu a mówimy prawdy Starego bądź też Nowego Testamentu albo też ogólnie prawdy zawarte w Piśmie św. Natomiast Nowy Testament ogłosił, że Prawda ciałem się stała. Interpretując pojęcie prawdy w nowym Testamencie św. Klemens Rzymski stwierdził, że nie tylko sam Chrystus jest Prawdą ale wszystko co głosi jest prawdą. Historia Kościoła jest świadkiem tego, jak atakowana przez heretyków prawda przeobraża się w dogmat. Kościół przez dwa tysiąclecia chroni dogmatyczne określenia świętych Soborów Powszechnych, które są fundamentem naszej wiary i gwarantem prawidłowego wzrastania w Chrystusie i ostatecznie naszego zbawienia.
\end{abstract}

Keywords: God, the world, a man, the truth, philosophy, Holy Scripture, salvation, dogma

Słowa kluczowe: Bóg, świat człowiek, prawda, filozofia, Pismo Św., zbawienie, dogmat

Wielcy myśliciele i filozofowie by znaleźć odpowiedzi na nurtujące ich pytania dotyczące tajemnicy świata i człowieka; skąd przybył, jaki sens ma jego życie i dokąd podąża, od dawien dawna poszukują wspólnej zasady obserwowanych przez siebie zjawisk, dążą do zintegrowania wielorakości świata poprzez sprowadzenie jej do jakiegoś jednolitego źródła, poszukują wyższej prawdy. Na samym początku człowiek uzasadniał genezę i funkcjonowanie świata za pomocą wymyślonych przez siebie mitów i bóstw, opracował subiektywny wyróżnik człowieczeństwa i w ten sposób tworzył swój pierwszy konstytutywny światopogląd. Ale prawdę należało zdefiniować. Przedsokratyczni filozofowie nie potrafili podać formalnie poprawnej definicji prawdy. Pierwszy, komu udało się zdefiniować pojęcie prawdy był Arystoteles. Ale takie światopoglądowo -filozoficzne rozumowanie podlegało procesowi ewolucji. Paralelnie obok wielkich centrów naukowych poszukujących odpowiedzi na nurtujące ówczesnego człowieka pytania istniał mikroskopijny świat Starego Testamentu, głoszący etyczny monoteizm, tzn., że nie ma wielu abstrakcyjnych bogów lecz, że jest tylko jeden odpowiedzialny za świat osobowy Stwórca, który wszystko co stworzył było dobre tzn. absolutnie doskonałe $(G e n$ 1,11). Ukoronowaniem zaś dzieł Stwórcy był człowiek, którego obdarzył On swoim obrazem- „, potem rzekł Bóg: Uczyńmy człowieka na nasz obraz, podobnego do nas i niech panuje nad rybami morskimi i nad ptactwem niebios, i nad bydłem i nad całą ziemią, i nad wszelkim płazem pełzającym po ziemi. I stworzył Bóg czło- wieka na obraz swój. Na obraz Boga stworzył go. Jako mężczyznę i niewiastę stworzył ich. I pobłogosławił im Bóg i rzekł do nich Bóg: Rozradzajcie się i rozmnażajcie się, i napełniajcie ziemię i czyńcie ją sobie poddaną..." (Gen 1,27-28). Należało by tu zwrócić baczniejszą uwagę na słowo „uczyńmy”, które w tradycji patrystycznej wskazuje na trynitarny charakter stworzenia oraz jedność woli i energii Trójjedynego Boga' ${ }^{1}$. Poddając głębszej analizie hermeneutycznej wyżej wymienioną sentencję św. Atanazy z Aleksandrii konstatuje, w duchu ap. Pawła, że Bóg tworzył przez Syna $^{2}$, Który, jest obrazem Boga niewidzialnego, pierworodnym wszelkiego stworzenia...ponieważ w Nim zostało stworzone wszystko, co jest na niebie i na ziemi...(Kol 1,15-16). Po tragicznym w następstwach wygnaniu ludzi z Raju, pierwszym wizualnym biorcą Bożego sygnału ,odnośnie tego, że Stwórca chce przywrócić relację z człowiekiem i zawrzeć z nim w przymierze, był Abraham. „I rzekł Pan do Abrahama: Wyjdź z ziemi swojej i od rodziny swojej i z domu ojca swego do ziemi, którą ci wskaże. A uczynię $\mathrm{z}$ ciebie naród wielki...ustanowię bowiem przymierze mię-

\footnotetext{
A.Patristic Greek Lexicon, edited by G. W. H. Lampe, DD.Oxford at the Clarendon Press, Oxford 1961, s. 1191.

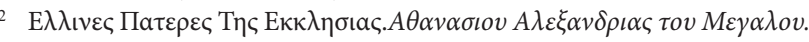

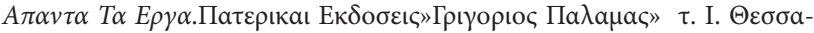
$\lambda$ оovıкп 1973, s. 78.

G. I. Mantzaridis, Przebóstwienie Człowieka. Nauka świętego Grzegorza Palamasa $w$ świetle tradycji prawosławnej, przełożyła Iga Czaczkowska, Lublin 1997, s. 29.
} 
dzy mną a tobą...obrzeżcie bowiem ciało napletka waszego i będzie to znakiem przymierza między mną a wami" (Gen 12,1-2; 17,2-14). „Potem ukazał mu się Pan w dąbrowie Mamre, gdzie siedział u wejścia do namiotu w skwarne południe. A podniósłszy oczy, ujrzał trzech mężów, którzy stanęli przed nim..." (Gen 18,1-2). Wraz z wypełnieniem się obietnicy złożonej przez Pana Abrahamowi, że z niego wywiedzie się wielki i potężny naród i w tym narodzie urodzi się potomek, któremu nadadzą imię Emmanuel-to znaczy Bóg z nami, na nowo pojawiło się zagadnienie wyjawienia istoty prawdy na kanwie dialogu Piłata, i w jego osobie całego pogańskiego Rzymskiego Imperium z Chrystusem. Pytanie Piłata co to jest prawda, zawierało w sobie różnicę i rozróżnienie pomiędzy osobową Prawdą, z jednej strony a potężnym politycznym i wszechwładnym autorytetem. Stwierdzenie Zbawiciela że ja jestem drogą żywotem prawdą nie pozostawiało w słuchaczach wątpliwości co do Jego niebiańskiego pochodzenia (J 14.6). Rozważając te słowa św. Klemens Rzymski dodaje, że nie tylko to sam Chrystus jest prawdą ale wszystko co głosi jest prawdą ${ }^{3}$ Tradycja patrystyczna interpretując ten epizod jednomyślnie stwierdza, że Chrystus milczał przed Piłatem ponieważ rzymski namiestnik będąc oślepiony pychą, swoim pytaniem powielał ówczesne błędne rozumienie prawdy, którą popularnie pojmowano jako idę̨ opartą na intelektualnej sile rozumu ludzkiego co prowadziło do politeizmu i panteizmu czyli organicznego utożsamiania bóstwa z przyrodą. Prawda, według Piłata, była prawdopodobnie jakąś spekulatywno-intelektualną filozoficzną ideą, głoszona przez któregoś z ówczesnych znanych filozofów bo - jak podkreślił M. Bierdiajew- „taka prawda jest fikcją, która nie zbawia człowieka, ponieważ bóg filozofów jest tworem bezosobowym i dlatego nie jest w stanie wejść w personalną relację z człowiekiem"4. Według rosyjskiego myśliciela, podobnie ma się rzecz we współczesnych hinduistycznych wierzeniach albo w buddyzmie ${ }^{5}$. Ale skoro Piłat nie rozpoznał w Chrystusie osobowej Prawdy, to tylko dlatego, że postawił błędne pytanie na które nie było odpowiedzi; należało natomiast zapytać, Kim jest Prawda?. Dla uczniów Chrystusa prawdą był On sam, oraz pojawienie się w Jego osobie Królestwa Bożego, czyli Królestwa miłości, sprawiedliwości i pokoju, które objawiło się w świecie jako Boża siła odkupująca i zbawiająca, jako źródło miłosierdzia i sprawiedliwości, jako łaska pozwalająca człowiekowi odróżnić duchy dobra od duchów $z^{\prime ł a}{ }^{6}$. Uczniowie pańscy by poznać Prawdę musieli przejść przez okres przygotowawczy, a wydarzenia w Getsemanii były probierzem ich wierności Prawdzie. A więc Prawda nie jest „rzeczą" lub oderwaną bezosobową ideą filozofów lecz samą Osobą naszego Zbawiciela i Pana który sam o sobie powiedział że jest prawdą, drogą i życiem $(J 14,6)$. Rozwijając ten temat matka Maria $\mathrm{z}$ Normanby w piękny

A.Patristic, Greek Lexicon, dz. cyt., s. 71

M. Bierdiajew, O Zniewoleniu i Wolności Człowieka, wyd. Ymca-Press, Clamart-Paris 1939, s.92.

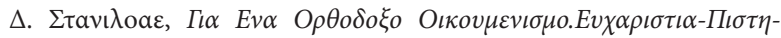

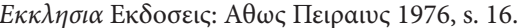

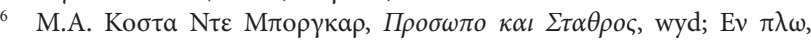
A prva 2014, s. 123. liryczny sposób pisze, że „dla nas prawda nie jest systemem myślenia. Prawda nie została stworzona. Prawda jest. Chrystus jest prawdą. Prawda jest osobą. Prawda nie jest ograniczona do naszego pojmowania. Prawda nas przewyższa; nigdy nie będziemy w stanie zrozumieć Prawdy. Poszukiwanie prawdy jest poszukiwaniem osoby Jezusa Chrystusa. Prawda jest Tajemnicą osoby Chrystusa, a ponieważ jest to osoba, Tajemnica jest nierozerwalnie związana $\mathrm{z}$ wydarzeniem spotkania. Tajemnica i wydarzenie to jedno. Dla prawosławnego umysłu ta tajemnica stanowi precyzyjna i surową rzeczywistość. Jest to Chrystus, ale i jest to spotkać Chrystusa"'. W Osobie Jezusa Chrystusa człowiek poznaje „drogę" pozwalającą mu poznać Prawdę, pozwala mu wejść w relację z Bogoczłowiekiem a tym samym wejść w relację z Ojcem bo „kto mnie widział, widział Ojca” (J 14,9). W Prawdzie Chrystusowej jest boska prostota. Prawdę zdobywa się życiem i poświęceniem, wysiłkiem woli i integralnością ducha a nie samym tylko intelektualnym poznaniem. Samo poznanie jest tylko funkcją życia religijnego. Ideałem prawosławia jest raczej święty „podwiżnik” a bardzo rzadko uniwersytecki profesor teologii, chociaż przykłady św. Justyna Popowicza czy ojca Dumitru Staniloe świadczą o tym, że i tacy też się zdarzali Ale wraz z Prawdą, jak pisze św. Paweł, istnieje również i łaska bo „Zakon bowiem został nadany przez Mojżesza, łaska zaś i prawda stała się przez Jezusa Chrystusa" (J 1,17). Bóg nikogo nie obdarza swoją łaską na siłę, ani tych którzy ją odrzucają ani tych, którzy kierują się w swoim życiu technikami samozbawienia. Łaska wspólistnieje z prawdą i nie ma jej tam gdzie odrzucana jest Prawda. Bo jeśli odrzucana jest Prawda, to odrzucany jest również dogmat, który ją wyraża. Kościół prawosławny i Pismo Święte nie akceptują zarówno chrześcijaństwa „adogmatycznego” bo coś takiego ograniczyło by chrześcijaństwo do życia w duchu post-reformacyjnego zachodniego „pietyzmu”, bądź też systemie zmiennych wartości moralnych oderwanych od fundamentu, na którym oparte są chrześcijańskie ewangeliczne prawdy o Bogu, zredagowane i ogłoszone $\mathrm{w}$ formie orzeczeń dogmatycznych na Soborach Powszechnych. Teoria protestanckiego teologa Harnacka, że dogmaty zracjonalizowały teologię chrześcijańską intelektualizmem i wniesieniem zasad filozofii greckiej, jest obalona przez historię Kościoła, która naucza że dogmaty miały mistyczny i antynomiczny charakter ${ }^{8}$, natomiast herezje próbując racjonalistycznie wytłumaczyć Boże tajemnice, usuwały za pomocą ludzkiego rozumu mistyczno-antynomiczny charakter dogmatów. Co więcej dogmaty chrześcijańskie nie są intelektualnymi teoriami ani metafizycznymi koncepcjami, lecz faktami, widzeniami, żywym doświadczeniem, które na przykład św. Paweł swoje „widzenia” wyraził w dogmacie odkupienia. „Czyż św. Atanazy Wielki - zapytuje prof. M. Bierdiajew - racjonalizował chrześcijaństwo $\mathrm{z}$ pomocą filozofii greckiej? Otrzymał on mądrość z ascetycznego wysiłku tych, co żyli na pustyni, którzy doświadczeniem zdobywa-

K. Ware, Prawosławna Droga, przełożyła siostra Nikołaia z monasteru Opieki Matki Bożej w Bussy-en-Othe, Białystok 1999, s. 91.

8 M. Bierdiajew Filozofia Wolności, tłum. Ewa Matuszczyk, Białystok 1995, s. 13. 
li światło. Filozofia nie jest potrzebna religijnym dogmatom, ale dogmaty religii potrzebne są filozofii, żywią ją, wtajemniczają w sekrety tego ,co ostateczne" "Zycie św. Atanazego i jego interpretacja Ewangelii odzwierciedlały duch egipskiej pustyni, a towarzyszący mu ascetyczny wysiłek wniosły na stałe do chrześcijańskiej teologii dogmat o przebóstwieniu ${ }^{10}$. Samo słowo „dogmat" pochodzi od

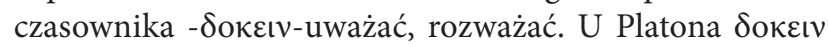
oznacza wyrażenie czyjejś prywatnej opinii to, co ktoś uważa za stosowne, pożyteczne, dobre ${ }^{11}$. Od znaczenia prywatnej opinii słowo to przeobraziło się w termin filozoficzny oznaczający jakąś filozoficzną prawdę, punkt widzenia czy też punkt zainteresowania danej szkoły filozoficznej ${ }^{12}$. U Plutarcha spotykamy np -wyrażenie prawdy

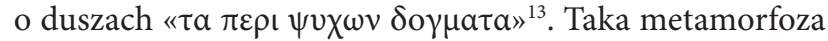

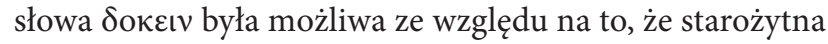
filozofia grecka miała charakter eklektyczny. Starożytni Grecy bardzo chętnie łączyli w jedną czasami całość, teorie, koncepcje, pojęcia, wybrane z różnych kierunków i doktryn filozoficznych. Z filozofii greckiej słowo to przedostało się do obiegu życia publicznego i zaczęło oznaczać jaką́s prawdę o charakterze polityczno-praw-

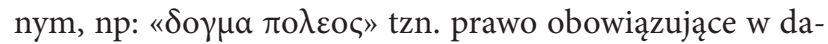
nym mieście ${ }^{14}$. Potwierdza to Ewangelia według św. Łukasza w sprawie edyktu cesarskiego odnośnie dokonania

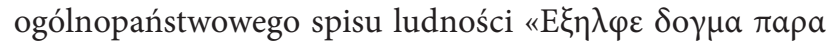

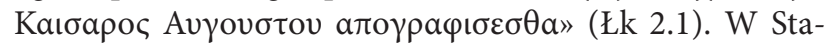
rym Testamencie i w Judaizmie słowo dogmat nosiło charakter religijno-prawny. Św. Paweł, nawiązując do klimatu Starego Testamentu, nadał temu słowu negatywne znacze-

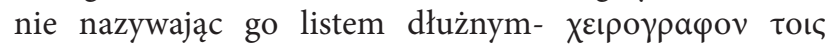

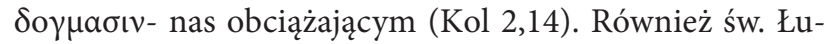
kasz w Dziejach Apostolskich pisze, że ,...gdy przechodzili

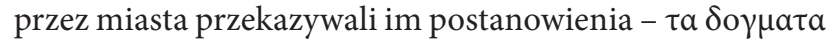
- powzięte przez apostołów i starszych w Jerozolimie aby je zachowywali (Dz 16,4). W okresie post-apostolskim oraz u wczesnych Ojców Kościoła słowo dogmat ma bardziej odniesienie do czynu- $\pi \rho \alpha \xi\left\llcorner\varsigma\right.$ - aniżeli do teorii ${ }^{15}$.

\section{Prawda wyrażona $w$ dogmacie}

Systematyczne studiowanie dogmatów Kościoła pojawia się w post-apologetycznej okresie historii Kościoła; po

\footnotetext{
M. Bierdiajew,Filozofia, dz. cyt., s.14.

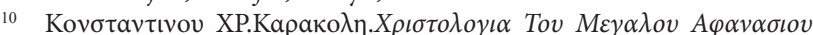
$\Theta \varepsilon \sigma \sigma a \lambda o v ı \kappa \eta 1968$, s. 68. W czternaście wieków później o ważności doświadczenia przebóstwienia-stiażanie Św. Ducha.- opowiedział nam i pokazał w sposób wizualny św. Serafin z Sarowa.

${ }_{11}$ Aristote, Ethique de Nicomaque.Texte,Traduction,Preface et Notes par Jean Voiquin, wyd. Clasiques Garnier Paris 1958, 298. A.Bally, Dictionnaire Grec-Francais, wyd. E. Egger. Hachette, 79, Boulevard SaintGermain, Paris 1950, s. 527.

12 Tamże, s. 528.

13 V. Ehenberg, The Cambridge Ancient History,vol V.Cambridge 1976, s. 347.

14 Aristote,Ethique de Nicomaque, s. 263.

15 Biblioteka Ojców Kościoła, Pierwsi świadkowie. Ignacy Antiocheński Do Kościoła w Magnezji 13,1 i List Barnaby 1,6. Pisma Ojców Kościoła, przekład Anna Świderkowna Kraków 1998.
}

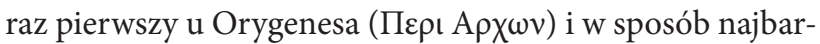
dziej kompleksowy w epoce patrystycznej u św. Jana z Damaszku(Wykład Wiary Prawosławnej). Dogmatyka jako oddzielny „dział” teologii, pojawiła się po raz pierwszy na Zachodzie w okresie Średniowiecza (Tomasz z Akwinu ,Summa Theologika) i w okresie Renesansu. Na gruncie prawosławnym dogmatyka pojawiła się w XVII w pod postacią tzw teologii omologijnej (Wyznanie Piotra Mogiły, Cyryla Lukarisa, Dosyteusa itd.). Na przełomie XVIII i XIX wieku problemem prawosławnej dogmatyki sposób systematyczny zajmował się grecki teolog Afanasios Parios „Epitomi” 1806, Moschopoulos „Epitomi dogmatykis kai ifikis theologias" 1851, Eugenios Woulgaris, a na gruncie rosyjskim w szczególności metropolici Moskwy Antonii i Makary. W XX wieku w Grecji, zachowując tę samą metodę i podział, czołowe miejsce w badaniach dogmatycznych zajęli Z. Rossos, X. I. Karmiris i P. Trembelas, Ch. Konstantynidis. Ch. Androutsos przedstawił naukowy klimat dominujący w ateńskiej szkole teologiczny odnośnie nauczania dogmatyki w tamtych czasach jednocześnie ubolewając, „że $\mathrm{w}$ jego czasach formuły dogmatyczne nie mają najmniejszego odniesienia do życia świętych i do pobożności kościelnej. Autentyczność dogmatyki nie jest już potwierdzona przez doświadczenie, nie jest połączona z etyką Kościoła $i$ jest głęboko ideologiczna" ${ }^{16}$. Nowy impuls do dogmatyki w XX wieku wniósł profesor Instytutu św. Sergiusza i Sorbony W. Łoski, o. Jerzy Florowski w Ameryce zaś na gruncie grecko-amerykańskim, ks. prof. Ioannis Romanidis, który w kursie teologii systematycznej, przeznaczył centralne miejsce palamickiemu rozróżnieniu istota-energie oraz podkreślał bardziej egzystencjonalny charakter dogmatu. Jego Dogmatyka jest wyraźnym przeciwieństwem Dogmatyki Androutsosa i Trembelasa. Również profesor Christos Jannaras przeciwstawiając się scholastycznym wpływom w prawosławnej XIX wiecznej dogmatyce słusznie odnotował, że „w prawosławiu dogmat wyraża doświadczenie Kościoła, a nie po prostu " teoretyczne zasady"17. Ks. metropolita Ioannis Zizulas podążając śladami paryskiej szkoły teologicznej, wniósł ogromny wkład do zrozumienia prawosławnej eklezjologii ${ }^{18}$. Tak więc dogmatyka w XX wieku jako oddzielna dyscyplina naukowa weszła na stałe do programu prawosławnych szkół teologicznych. Dziedzina ta w porównaniu $\mathrm{z}$ innymi gałęziami teologii, wyróżnia się tym ,że posiada charakter metodyczny albo też innymi słowy systematyczny i dlatego czasami nazywana jest teologią systematyczną, który możemy podzielić na następujące podrozdziały:

1. Chrystologiczne hymny ap. Pawła skierowane do pierwszych społeczności chrześcijańskich; np. do Filipian. Zawierają one treści wyrażające teologiczno-dogmatyczne poglądy Apostoła narodów.

\footnotetext{
${ }^{16}$ K. Ch. Felmy, Wspótczesna teologia prawosławna, przełożył ks. Henryk Paprocki, Białystok 2005, s. 16.

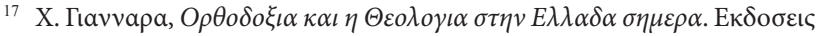
A@HNA, 1979, s. 95.

${ }^{18}$ J. D. Zizulas, Eucharist Bishop Church.The unity of the church in the Divine Eucharist and the bishop during the first three Centuries, Holy Cross Orthodox Press, Brookline Massachusetts 2001.
} 
2. Ewangelia według św. Jana pomimo głęboko dogmatycznego prologu i teologicznego charakteru tekstu w pewnej części jest postrzegana przez wielu również jako zawierająca treści liturgiczne.

3. Pierwszy list ap. Piotra zawiera w swej treści liturgię baptyzmalną. Z niej to wywodzą się eucharystyczne anafory pierwszych wieków, które są tworem profetyczno-charyzmatycznej teologii św. Justyna i Didache.

4. Baptyzmalny charakter dogmatyki wraz z przygotowawczą katechezą. Jest to najważniejsze źródło teologii symbolicznej (również symboli wiary). W pierwszych wiekach wszystkie symbole wiary jakich używano w Kościele miały charakter baptyzmalny. Na przykład pierwszy Sobór Ekumeniczny za podstawę dla zredagowania swego symbolu wiary posłużył się wszystkimi znanymi symbolami wiary będącymi w użyciu przez kościoły lokalne.

5. Anty-heretycki charakter dogmatyki dał impuls dla rozbudowy starożytnych symboli baptyzmalnych w szersze i bardziej rozwinięte symbole w celu odparcia ataków takich heretyków jak Gnostycy, Arianie itp. $\mathrm{Na}$ tej płaszczyźnie istotne znaczenie dla dogmatyki posiada teologia patrystyczna takich Ojców Kościoła jak św. Ireneusz, św. Atanazy i św. Cyryl z Aleksandrii, Ojcowie Kapadoccy oraz św. Maksym Wyznawca. Teologia ta rozwinęła się jako antyteza a nie jako pozytywny wykład wiary.

6. Na synodalny charakter dogmatyki wpłynęły orzeczenia wielkich Soborów Powszechnych, które powstały w wyniku zintegrowania elementów anty-heretyckiej teologii z teologią baptyzmalno-symboliczną. Ale nie tylko orzeczenia soborowe i symbole wypracowane przez mniejsze synody miały istotny wpływ na powstanie teologii dogmatycznej. Również kanony wielkich Soborów i mniejszych synodów posłużyły za podstawę dla powstania dogmatyki.

7. Empiryczny charakter dogmatyki wypływa również $\mathrm{z}$ mistycznych przeżyć wielkich mnichów pustyni ( $\mathrm{w}$ apofmegaty) oraz z pism św. Jana Klimaka, św. Maksyma Wyznawcy, św. Symeona Nowego Teologa oraz z całej tradycji hezychastycznej skupionej wokół i wyrażonej przez św. Grzegorza Palamasa. Wyrażają oni teologię dogmatyczną za pośrednictwem przeżyć mistycznych. Nieco szerzej empiryczny charakter dogmatu wyjaśnia prof. Włodzimierz Łosski słusznie konstatując, że „dogmat, wyrażający Prawdę Objawioną, która jawi się nam jako niezgłębiona tajemnica, musi być przez nas przeżyty: $\mathrm{w}$ procesie tego przeżycia, zamiast dostosować tajemnicę do naszego sposobu rozumienia, powinniśmy-przeciwnie-czuwać nad głęboką zmianą, nad wewnętrznym przeobrażeniem naszego umysłu aby stać się zdolnymi do doświadczenia mistycznego. Teologia i mistyka nie są sobie przeciwstawne, lecz posiłkują się nawzajem i uzupełniają. Jedna nie może istnieć bez drugiej. W oderwaniu od prawdy strzeżonej przez cały Kościól, doświadczenie prywatne byłoby pozbawione wszelkiej pewności, wszelkiej obiektywności, było by mieszaniną prawdy i fałszu, rzeczywistości i złudzenia... $Z$ drugiej strony-nauczanie Kościoła nie miałoby żadnego wpływu na dusze, gdyby nie wyrażało w jakiś sposób wewnętrznego doświadczenia prawdy..." ${ }^{\prime \prime}$.

Również Christos Jannaras, wiążąc kwestię dogmatu $\mathrm{z}$ doświadczeniem mistycznym, stwierdza. że doświadczenie mistyczne nie może posiadać charakteru pietystycznego lub moralnego, lecz powinno posiadać charakter ontologiczno-egzystencjonalny, ponieważ sfera dogmatyki ogarnia swoim zainteresowaniem sferę bytu (gr. $\tau o$ ov- albo

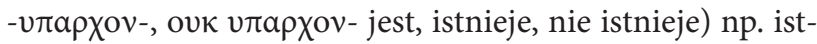
nienie Boga, życia, stworzenia, osoby, miłości wolności, grzechu, zła, odkupienia. Dogmatyka interesuje się tematami egzystencjonalnymi ale o soteriologicznym znaczeniu. Cerkiew dogmatyzuje przede wszystkim po to by zbawić a nie po to by poszerzyć naszą wiedzę o Bogu i świecie. Każdy jej dogmat lub synodalno-dogmatyczna decyzja ma zawsze odniesienie do problemu zbawienia człowieka, podkreśla w/w teolog ${ }^{20}$. Patriarcha Konstantynopola, Bartłomiej I w swej znakomitej książce pt. „Prawda was wyzwoli” doskonale wczuwając się w aurę neopatrystycznych tendencji dodaję, że „dogmaty w żadnym razie nie stanowią systemu, lecz chronią drogę życia, otwierają na kontemplację poprzez negację, symbol i antynomię" ${ }^{\prime 21}$. Należy również pamiętać o tym, że wielkie spory teologiczne okresu patrystycznego nie miały charakteru ani abstrakcyjnego ani intelektualnego ale miały charakter soteriologiczno egzystencjonalny ${ }^{22}$.

Prawosławna dogmatyka posiada więc bardziej charakter witalny, empiryczny, aniżeli logiczny czy hipotetyczny $^{23}$.

\section{Skryptualny wymiar Prawdy}

Ks. metropolita J. Zizulas stwierdza, że relacja dogmatu do Pisma św. ma charakter hermeneutyczny. Według niego problem relacji pomiędzy Biblią a dogmatem pojawił się zachodniej teologii w okresie post-reformacyjnym, kiedy to reformatorzy odrzucili Tradycję Kościoła a przyjęli Pismo Św. (tzw. sola scriptura) za jedyne źródło Bożego Objawienia ${ }^{24}$. W Kościele prawosławnym problem ten pojawił się z momentu napisania tzw. Ksiąg Symbolicznych w których to metropolita Piotr Mogiła ustosunkował się do pozycji rzymskokatolickiej, natomiast Cyryl Lukaris

\footnotetext{
${ }^{19}$ M. Łoski, Teologia Mistyczna Kościoła Wschodniego, przełożyła Maria Szczaniecka, Instytut wydawniczy Pax, Warszawa 1989, s. 6-7.

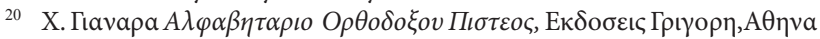
1977, s. 13.

${ }_{21}$ O. Clement Prawda was wyzwoli.Rozmowy $z$ Patriarcha ekumenicznym Bartłomiejem I, Verbinum. Wydawnictwo Księży Werbistów, Warszawa 1998, s. 20.

${ }^{22}$ A. Schmeman,Church World Mission, St. Vladimir's Seminary Press, Crestwood NY 10707 1970, s. 47.

${ }^{23}$ Chodzi tutaj o problem tzw. szkolnej teologii która wdarła się do prawosławnych szkół teologicznych w XVIIII i XIX w.

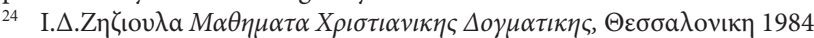
-maszynopis, s. 21.
} 
do pozycji kalwińskiej. Kilka wątków było przyczyną pojawienia się tej kwestii na Zachodzie. Głównie z powodu interpretacji i egzegezy Pisma Św. w duchu filiokwistycznej teologii św. Augustyna i Scholastyki. Św. Augustyn nie potrafiąc rozróżnić Boskiej istoty od jej naturalnych energii - jak to czyniono na Wschodzie- doprowadził do bardzo szczególnej interpretacji Biblii, w której stworzenia lub symbole zaczęły istnieć w celu przekazywania boskiej wiadomości, a potem odejścia w niebyt. Idąc tym śladem Biblia stała się księgą zawierającą opis niewiarygodnych cudów, mitów, sag i religijnych przygód. W celu tzw. odmitologizowania biblijnych przekazów protestanci użyli tzw. literacko-krytycznej metody, która potraktowała Biblię nie jako źródło Bożego Objawienia ale bardziej jako historyczny zabytek literacki ${ }^{25}$. Natomiast w Prawosławiu Objawienie ma zawsze charakter egzystencjalno osobowy a nie naukowo-egzegetyczny. Bóg objawia się Abrahamowi, Mojżeszowi, ap. Pawłowi, Ojcom Kościoła (np. św. Symeon Nowy Teolog) w postaci Bożej niestworzonej chwały. Dlatego Sobory Powszechne odwołują się nie tylko do Ojców w Biblii ale także do Ojców wszystkich wieków jako uczestniczących w tej samej Prawdzie, która jest Bożą chwałą w Chrystusie ${ }^{26}$. Czysta egzegeza, jako nauka autonomiczna nie istniała za czasów Ojców. Co prawda szkoła antiocheńska posługiwała się metodą historyczno-gramatyczną, natomiast aleksandryjska stosowała alegoryczną metodę ale żadna $\mathrm{z}$ nich nie poddawała krytyce literackiej lub wątpliwości samego tekstu biblijnego. Oczywiście hermeneutyka na Wschodzie miała ogromne znaczenie, chociażby idąc za przykładem dwóch wyżej wymienionych szkół egzegetycznych ale tym nie mniej zachowały one ogromny szacunek dla treści biblii jako słowa samego Boga, słowa, którego wiarygodność żadne ze stworzeń nie ma prawa poddać wątpliwości. Ojcowie Kościoła posługując się treścią Biblii bronili dogmatycznej prawdy Kościoła, ponieważ jak podkreśla P. Ewdokimow prawda dogmatyczna zawiera nieomylny sens najważniejszych tekstów biblijnych, dany Kościołowi przez samego Boga.

Biblia jest nie tylko źródłem prawd dogmatycznych ale źródłem modlitewnego doświadczenia, prośbą do Boga by objawił swoją wolę, by „otworzył umysł” proszącemu, podobnie jak to uczynił Chrystus swym uczniom podążającym do Emaus (Łk 24,15). Podobnie celebrans podczas sprawowania Św. Liturgii przed czytaniem św. Ewangelii zwraca się do Boga prosząc „Rozjaśnij w naszych sercach, Panie miłujący człowieka, promienie niegasnącego światła poznania Twego bóstwa i otwórz oczy naszego umysłu, abyśmy mogli pojąć orędzie Twej Ewangelii. Wzbudź w nas także bojaźń wobec Twoich świętych przykazań, abyśmy, przezwyciężywszy wszelkie pragnienia zmysło-

\footnotetext{
25 Wydaje mi się, że to wschodnie traktowanie z najwyższym autorytetem Słowa Bożego znalazło swoje odzwierciedlenie w Koranie.

26 W. Doroszkiewicz Dzieje Wschodnich Rzymian, Białystok 2012, s. 316.
}

we, prowadzili życie według ducha, myśląc i działając według Twojego upodobania"27. Wartym jest przypomnienia fakt, że powszechna tradycja czytania psałterza jest tak stara jak Biblia. W antiocheńskiej tradycji monastycznej do klasztoru nie przyjmowano nikogo ,kto nie znał tekstu wszystkich psalmów na pamięć. $\mathrm{W}$ programie modlitewnym wielkich świętych mnichów, Pismo św. było regularnie traktowane jako tekst modlitewny. Św. Serafin z Sarowa czytał w ciągu tygodnia czytał cztery Ewangelie stojąc na kolanach. Należy również zauważyć, że wraz z przeniesieniem przez św. Paisjusza Wieliczkowskiego na grunt słowiański tradycji hezychastycznej, nastąpiło zainteresowanie tekstem Pisma św. Na długo jeszcze przed pojawieniem się Brytyjskiego Towarzystwa Biblijnego dzięki wysiłkom tego wielkiego świętego mnicha w mołdawskich monasterach powstały cale ośrodki zajmujące się pracą translatorsko-wydawniczą.

\section{Zakończenie}

Podsumowujac należy stwierdzić, że od samego początku samo pojęcie prawdy, zanim osiągnęło dogmatyczną elaborację przeszło przez cykl bardzo głębokiej ewolucji, aczkolwiek sama prawda w sensie substancjalnym pozostaje niezmienna stała i wieczna. Inaczej sens prawdy pojmowali starotestamentowi patriarchowie w kananejskiej pustyni a inaczej ich potomkowie. Aczkolwiek prawda jest wieczna i niezmienna i wieczna, to każda epoka wyrażała i wyraża ją swoim językiem, który stanowi strategiczną część kultury i historii danego narodu. Św. Apostołowie, prości rybacy z Galilei, stali się godni i szczęśliwi, zobaczyć i usłyszeć Prawdę, „która ciałem się stała" (J 1,14). Ten stan szczególnego błogosławieństwa które spłynęło na apostołów potwierdza sam Chrystus mówiąc: „Bo zaprawdę powiadam wam: Wielu proroków i sprawiedliwych pragnęło ujrzeć to, co wy widzicie, a nie ujrzeli, i usłyszeć to, co wy słyszycie, a nie usłyszeli" (Mt 13, 17). Natomiast Piłat, przedstawiciel tego świata, namiestnik najpotężniejszego w tamtych czasach Imperium Rzymskiego trwając w swej pysze nie rozpoznał Prawdy. Podobnie i my coraz mniej rozpoznajemy ją dzisiaj. Czyżby się ukryła, czy też my sami coraz częściej hołdując wielu przyziemnych pseudo -prawdom usprawiedliwiamy siebie tłumacząc, że znowu wąż nas zwiódł proponując w zamian do skosztowania owoce dobre do jedzenia... miłe dla oczu i godne pożądania dla zdobycia mądrości. Ale skoro świat bowiem-pisze św. Paweł- przez mądrość swoją nie poznał Boga w Jego Bożej mądrości...my zaś zwiastujemy Chrystusa ukrzyżowanego, który jest mocą Bożą i mądrością Bożą.

Boska Liturgia św. Jana Chryzostoma, Warszawa 2001. 


\section{Bibliografia}

Bierdiajew M., Filozofia Wolności, tłumaczyła Ewa Matuszczyk, Białystok 1995.

Bierdiajew M., O Uniżeniu i Swobode czełowieka, wyd. YmcaPress, Clamart-Paris 1939.

Clement O., Prawda was wyzwoli. Rozmowy z Patriarcha ekumenicznym Bartłomiejem I, Verbinum Wydawnictwo Księży Werbistów, Warszawa 1998.

Felmy K. Ch., Współczesna teologia prawosławna, przełożył ks. Henryk Paprocki, Białystok 2005.

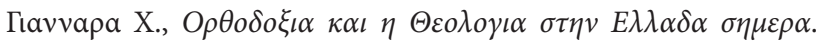

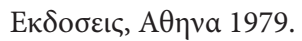

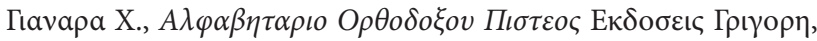
AӨpva 1977.

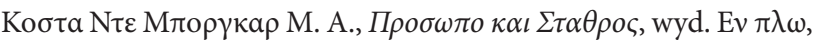
Apqua 2014.

Ware K., Prawosławna Droga, przełożyła siostra Nikołaia z monasteru Opieki Matki Bożej w Bussy-en-Othe, Białystok 1999.

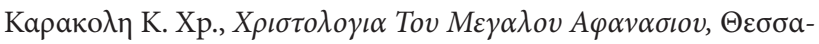

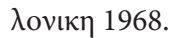

Łosski M., Teologia Mistyczna Kościoła Wschodniego, przełożyła Maria Szczaniecka, Instytut wydawniczy Pax, Warszawa 1989.

Mantzaridis G. I., Przebóstwienie Człowieka. Nauka świętego Grzegorza Palamasa $w$ świetle tradycji prawosławnej, przełożyła Iga Czaczkowska, Lublin 1997.

Schmeman A., Church World Mission, St. Vladimir's Seminary Press, Crestwood NY 107071970.

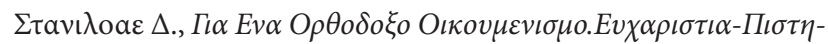

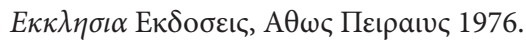

Zizulas J. D., Eucharist Bishop Church. The unity of the church in the Divine Eucharist and the bishop during the first three Centuries, Holy Cross Orthodox Press, Brookline Massachusetts 2001.

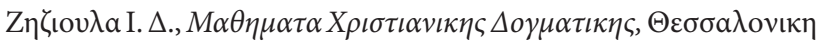
1984 -maszynopis.

Doroszkiewicz W., Dzieje Wschodnich Rzymian, Białystok 2012.

\section{Teksty źródłowe}

Aristote, Ethique de Nicomaque. Texte,Traduction,Preface et Notes par Jean Voiquin. wyd Clasiques Garnier Paris 1958.

Biblioteka Ojców Kościoła, Pierwsi świadkowie. Ignacy Antiocheński Do Kościoła w Magnezji 13,1 i List Barnaby 1,6. Pisma Ojców Kościoła, przekład Anna Świderkowna Kraków 1998.

Biblia. Nowy przekład z języków hebrajskiego i greckiego opracowany przez Komisję Przekładu Pisma Świętego. Brytyjskie i Zagraniczne Towarzystwo Biblijne, Warszawa 1976.

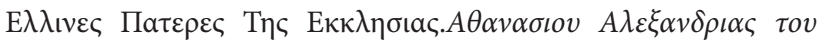

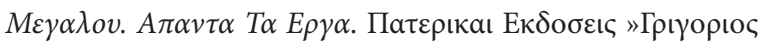

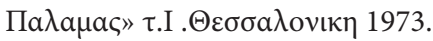

Ehenberg V., The Cambridge Ancient History,vol V, Cambridge 1976.

\section{Słowniki i leksykony}

A. Bally, Dictionnaire Grec-Francais, wyd. E.Egger, Hachette 79, Boulevard Saint-Germain, Paris 1950.

A Patristic Greek Lexicon, edited by G.W.H.Lampe, DD. Oxford at the Clarendon Press, Oxford 1967.

Rozmiar artykułu: 0,75 arkusza wydawniczego 